Article

\title{
Synthesis of $\mathrm{Bi}_{2} \mathrm{~S}_{3} / \mathrm{BiVO}_{4}$ Heterojunction with a One-Step Hydrothermal Method Based on $\mathrm{pH}$ Control and the Evaluation of Visible-Light Photocatalytic Performance
}

\author{
Deqiang Zhao ${ }^{1,2}$, Wenwen Wang ${ }^{3}$, Wenjuan Zong ${ }^{1,2}$, Shimin Xiong ${ }^{1,2}$, Qian Zhang ${ }^{1,2}$, \\ Fangying $\mathrm{Ji}^{1,2, *}$ and $\mathrm{Xuan} \mathrm{Xu}^{1,2, *}$ \\ 1 Key Laboratory of Three Gorges Reservoir Region's Eco-Environment Ministry of Education and National \\ Centre for International Research of Low-Carbon and Green Buildings, Chongqing University, \\ No. 174 Shazhengjie, Shapingba, Chongqing 400045, China; a2006silent@foxmail.com (D.Z.); \\ zongwenjuan1992@163.com (W.Z.); 18512341504@163.com (S.X.); zhangqiancqu@126.com (Q.Z.) \\ 2 National Centre for International Research of Low-Carbon and Green Buildings, Chongqing University, \\ Chongqing 400045, China \\ 3 Faculty of Urban Construction and Environment Engineering, Chongqing 400045, China; \\ www-vermeer@foxmail.com \\ * Correspondence: jfy@cqu.edu.cn (F.J.); xuxuan@cqu.edu.cn (X.X.); \\ Tel.: +86-(0)-65127537 (F.J.); +86-(0)-13637932203 (X.X.)
}

Received: 11 June 2017; Accepted: 28 July 2017; Published: 2 August 2017

\begin{abstract}
The band gaps of bismuth vanadate $\left(\mathrm{BiVO}_{4}\right)$ and bismuth sulfide $\left(\mathrm{Bi}_{2} \mathrm{~S}_{3}\right)$ are about $2.40 \mathrm{eV}$ and $1.30 \mathrm{eV}$, respectively. Although both $\mathrm{BiVO}_{4}$ and $\mathrm{Bi}_{2} \mathrm{~S}_{3}$ are capable of strong visible light absorption, electron-hole recombination occurs easily. To solve this problem, we designed a one-step hydrothermal method for synthesizing a Bismuth sulfide $\left(\mathrm{Bi}_{2} \mathrm{~S}_{3}\right) /$ Bismuth vanadate $\left(\mathrm{BiVO}_{4}\right)$ heterojunction using polyvinylpyrrolidone K-30 (PVP) as a structure-directing agent, and 2-Amino-3-mercaptopropanoic acid (L-cysteine) as a sulfur source. The $\mathrm{pH}$ of the reaction solution was regulated to yield different products: when the $\mathrm{pH}$ was 7.5, only monoclinic $\mathrm{BiVO}_{4}$ was produced (sample 7.5); when the $\mathrm{pH}$ was 8.0 or 8.5 , both $\mathrm{Bi}_{2} \mathrm{~S}_{3}$ and $\mathrm{BiVO}_{4}$ were produced (samples 8.0 and 8.5); and when the $\mathrm{pH}$ was 9.0, only $\mathrm{Bi}_{2} \mathrm{~S}_{3}$ was produced (sample 9.0). In sample 8.0, $\mathrm{Bi}_{2} \mathrm{~S}_{3}$ and $\mathrm{BiVO}_{4}$ were closely integrated with each other, with $\mathrm{Bi}_{2} \mathrm{~S}_{3}$ particles formed on the surface of concentric $\mathrm{BiVO}_{4}$ layers, but the two compounds grew separately in a $\mathrm{pH}$ solution of 8.5. Visible-light photocatalytic degradation experiments demonstrated that the degradation efficiency of the $\mathrm{Bi}_{2} \mathrm{~S}_{3} / \mathrm{BiVO}_{4}$ heterojunction was highest when prepared under a $\mathrm{pH}$ of 8.0. The initial rhodamine $\mathrm{B}$ in the solution $(5 \mathrm{mg} / \mathrm{L})$ was completely degraded within three hours. Recycling experiments verified the high stability of $\mathrm{Bi}_{2} \mathrm{~S}_{3} / \mathrm{BiVO}_{4}$. The synthesis method proposed in this paper is expected to enable large-scale and practical use of $\mathrm{Bi}_{2} \mathrm{~S}_{3} / \mathrm{BiVO}_{4}$.
\end{abstract}

Keywords: heterojunction; photocatalysis; hydrothermal method; bismuth vanadate; bismuth sulfide; $\mathrm{pH}$ value

\section{Introduction}

Semiconductors such as bismuth oxybromide-bismuth oxyiodide [1], $\beta-\mathrm{ZnMoO}_{4}$ [2], metal-organic frameworks (MOFs) [3], and BiOxIy/GO [4] can facilitate the photodegradation of dyes. Bismuth oxides and their composites (e.g., bismuth oxyiodides [5], bismuth oxyiodide/graphitic carbon nitride [6], and $\mathrm{BiO}_{x} \mathrm{I}_{y}$ /GO [7]) have been widely used for photocatalytic degradation of dyes, owing to their superior photocatalytic traits. Bismuth vanadate $\left(\mathrm{BiVO}_{4}\right)$ has the advantages of no 
toxicity, low cost, high chemical stability, photocorrosion resistance, and strong response to visible light $\left(E_{\mathrm{g}} \sim 2.40 \mathrm{eV}\right)$ [8]. However, because $\mathrm{BiVO}_{4}$ has a limited visible absorption range $(<525 \mathrm{~nm})$, and its electrons and holes recombine easily, the widespread application of this material is limited [9]. To improve the photocatalytic efficiency of $\mathrm{BiVO}_{4}$ under visible radiation, it is necessary to expand its visible absorption range, and limit the recombination of electrons and holes. On this basis, researchers have made considerable efforts towards $\mathrm{BiVO}_{4}$ modification.

Doping is the most frequently used method for improving the visible absorption range of $\mathrm{BiVO}_{4}$. For instance, $\mathrm{BiVO}_{4}$ has been doped with rare earth metals (e.g., $\mathrm{Bi}_{4} \mathrm{~V}_{2-x} \mathrm{M}_{x} \mathrm{O}_{11-x}(\mathrm{M}=\mathrm{Gd}, \mathrm{Nd}, \mathrm{Gd}$, $\mathrm{M}=\mathrm{Nd}$ ) [10]), europium [11], transition metals (e.g., Ag-doped $\mathrm{BiVO}_{4}$ [12] and $\mathrm{Pd} / \mathrm{BiVO}_{4}$ [13]), and $\mathrm{C}[14,15]$. These doping systems can effectively reduce the band gap of $\mathrm{BiVO}_{4}$ and increase its visible absorption range. However, these methods may elevate costs due to the use of precious metals, and increase heavy metal pollution. In addition, excessive doping may enhance electron-hole recombination.

A common method to restrain the recombination of electron-hole pairs is to construct a heterojunction. A number of studies have reported the synthesis of heterojunctions such as $\mathrm{WO}_{3} / \mathrm{BiVO}_{4}$ [16], $\mathrm{CaFe}_{2} \mathrm{O}_{4} / \mathrm{BiVO}_{4}$ [17], $\mathrm{BiOCl} / \mathrm{BiVO}_{4}$ [18], and $\mathrm{CO}_{3} \mathrm{O}_{4} / \mathrm{BiVO}_{4}$ [19]. Although these heterojunctions effectively restrain the separation of electron-hole pairs, they do not have an expanded visible adsorption range.

Bismuth sulfide $\left(\mathrm{Bi}_{2} \mathrm{~S}_{3}\right)$ is a p-type semiconductor $\left(E_{\mathrm{g}} \sim 1.30 \mathrm{eV}\right)$ [20] with a narrow band gap and a very strong response to visible light. The valence band (VB) position of $\mathrm{Bi}_{2} \mathrm{~S}_{3}$ is more negative than that of $\mathrm{BiVO}_{4}$, whereas the conduction band (CB) position of $\mathrm{Bi}_{2} \mathrm{~S}_{3}$ is more positive [21]. Therefore, $\mathrm{Bi}_{2} \mathrm{~S}_{3}$ can be combined with n-type semiconductor $\mathrm{BiVO}_{4}$ to form a heterojunction with a strong capacity for visible light absorption. Using thioacetamide as a sulfur source, De-Kun Ma et al. [22] developed a two-step hydrothermal method to synthesize olive-shaped $\mathrm{Bi}_{2} \mathrm{~S}_{3} / \mathrm{BiVO}_{4}$ microspheres with a limited chemical conversion route and enhanced photocatalytic activity. Canjun Liu et al. [23] used thiourea as a sulfur source in a two-step method for synthesizing $\mathrm{Bi}_{2} \mathrm{~S}_{3}$ nanowires on $\mathrm{BiVO}_{4}$ nanostructures with enhanced photoelectrochemical performance. Xuehui Gao et al. [24] studied the enhanced photoactivity of mesoporous heterostructured $\mathrm{Bi}_{2} \mathrm{~S}_{3} / \mathrm{BiVO}_{4}$ hollow discoid prepared using $\mathrm{Na}_{2} \mathrm{~S} \cdot 9 \mathrm{H}_{2} \mathrm{O}$ as a sulfur source.

In this work, we developed a simple one-step method to synthesize a $\mathrm{Bi}_{2} \mathrm{~S}_{3} / \mathrm{BiVO}_{4}$ heterojunction using the amino acid L-cysteine as a sulfur source. We added the sulfur source during the preparation of $\mathrm{BiVO}_{4}$ using a one-step hydrothermal method, and then regulated the $\mathrm{pH}$ of the system to cause $\mathrm{Bi}_{2} \mathrm{~S}_{3}$ to form on the $\mathrm{BiVO}_{4}$, thereby creating the $\mathrm{Bi}_{2} \mathrm{~S}_{3} / \mathrm{BiVO}_{4}$ heterojunction. We found that this complex material demonstrated a strong capacity for visible light absorption and separation of electron-hole pairs. The use of the heterojunction as a catalyst for rhodamine B ( $R h B)$ degradation was investigated under visible light irradiation, and possible formation and degradation mechanisms strongly affected by $\mathrm{pH}$ were proposed. The results indicate that this complex material has potential for use in environmental and optoelectronic applications.

\section{Materials and Methods}

\subsection{Materials and Reagents}

The materials included analytical grade pure bismuth nitrate $\left(\mathrm{Bi}\left(\mathrm{NO}_{3}\right)_{3} \cdot 5 \mathrm{H}_{2} \mathrm{O}\right.$ (Chengdu Industrial Development Zone Xinde Mulan, Chengdu, China), analytical grade pure sodium hydroxide powder ( $\mathrm{NaOH}$, Chongqing Chuandong Chemical Company, Chongqing, China), analytical grade polyvinylpyrrolidone K-30 (PVP) (Chengdu Kelong Chemical Co., Ltd., Chengdu, China), ammonium metavanadate $\left(\mathrm{NH}_{4} \mathrm{VO}_{3}\right.$, Chongqing Chuandong Chemical Company, Chongqing, China), L-cysteine (Aladdin Industrial Corporation, Shanghai, China), rhodamine B (RhB, Tianjin Guangfu Fine Chemical Research Institute, Tianjin, China), nitric acid $\left(\mathrm{HNO}_{3}\right.$, Chengdu Area of the Industrial Development Zone Xinde Mulan, Chengdu, China), ethylene glycol, $\left(\mathrm{C}_{4} \mathrm{H}_{4} \mathrm{O}_{6} \mathrm{KNa}_{4} \cdot \mathrm{H}_{2} \mathrm{O}\right)$, silver 
nitrate $\left(\mathrm{AgNO}_{3}\right)$, p-benzoquinone (PBQ), and isopropanol (IPA) (Chongqing Chuandong Chemical Company, Chongqing Chuandong, China).

\subsection{Synthesis of Photocatalysts}

The $\mathrm{pH}$ of the reaction solution was set to $7.5,8.0,8.5$, or 9.0 (Sample-7.5, Sample-8.0, Sample-8.5, and Sample-9.0, respectively). During synthesis, $2 \mathrm{mmol} \mathrm{Bi}\left(\mathrm{NO}_{3}\right) \cdot 5 \mathrm{H}_{2} \mathrm{O}$ and $0.6 \mathrm{mmol} \mathrm{L}$-cysteine were dissolved in $4 \mathrm{~mL}$ of $4 \mathrm{~mol} / \mathrm{L} \mathrm{HNO}_{3}$. Then, $50 \mathrm{~mL}$ of deionized water was added to the solution, and the mixture was stirred for $30 \mathrm{~min}$ to obtain solution A. Similarly, $2 \mathrm{mmol} \mathrm{NH} 4 \mathrm{VO}_{3}$ was dissolved in $4 \mathrm{~mL}$ of $2 \mathrm{~mol} / \mathrm{L} \mathrm{NaOH}$, and the mixture was stirred for $30 \mathrm{~min}$ to obtain solution B. Solutions A and $\mathrm{B}$ were mixed together, and the $\mathrm{pH}$ was adjusted to $7.5,8.0,8.5$, or 9.0 using $\mathrm{NaOH}$ or $\mathrm{HNO}_{3}$. The solutions were transferred into a 100-mL, Teflon-lined autoclave, heated at $180{ }^{\circ} \mathrm{C}$ for $16 \mathrm{~h}$, and allowed to cool to room temperature. Finally, the solutions were centrifuged to obtain the final products. The samples were rinsed with distilled water and ethanol six times, and the $\mathrm{pH}$ of the filtrate was measured after the last rinse. If the $\mathrm{pH}$ of a sample was not neutral, the sample was further rinsed until a $\mathrm{pH}$ of $\sim 7$ was obtained. Then, the products were dried at $60^{\circ} \mathrm{C}$ for $12 \mathrm{~h}$ in vacuum.

\subsection{Characterization}

The crystal structures of prepared samples were characterized using X-ray diffraction (XRD) under CuK radiation with a Rigaku D/Max2500pc (Tokyo, Japan) diffractometer (scanning angle $2 \theta$ from $10^{\circ}$ to $70^{\circ}$, and scanning rate of $\left.4^{\circ} / \mathrm{min}\right)$. A high-voltage $(10 \mathrm{kV})$ Tescan FEG-SEM microscope (TESCAN, MARI3, Brno, Czech Republic) was used to acquire scanning electron microscopy (SEM) images of the prepared samples, and the elemental composition was characterized with an energy dispersive X-ray detector (EDX). A JEM-3010 electron microscope (JEOL, Tokyo, Japan) was used to perform transmission electron microscopy (TEM) at an acceleration voltage of $300 \mathrm{kV}$. Fourier transform infrared (FT-IR) spectra of prepared samples were recorded on a Shimadzu IR Prestige-1 spectrometer (Tokyo, Japan) using the KBr pellet technique. The chemical characteristics of sample surfaces were investigated using X-ray photoelectron spectra (XPS) acquired with a PHI5000 (ULVAC-PHI,INC., Kanagawa Prefecture, Japan) versa probe system under monochromatic Al K X-rays. A Hitachi U-3010 UV-Vis spectrophotometer (Tokyo, Japan) was used to perform UV-Vis diffuse reflectance spectroscopy (UV-Vis DRS) using the "Abs" data mode. The photoluminescence (PL) spectra of the photocatalysts were obtained using a Hitachi F-7000 (Tokyo, Japan) spectrometer with an excitation wavelength of $280 \mathrm{~nm}$. A CHI Electrochemical Workstation (CHI 760E, Shanghai Chenhua Co., Ltd., Shanghai, China) was used to evaluate the photoelectrochemical properties of the samples. The visible light source was a $500 \mathrm{~W}$ Xe lamp (with a $<400 \mathrm{~nm}$ UV cutoff filter), and all experiments were carried out at room temperature.

\subsection{Evaluation of Photocatalytic Activity}

The photocatalytic activity of samples was evaluated under visible radiation at room temperature by measuring the degradation rate of RhB. For the experiments, $0.20 \mathrm{~g}$ of catalyst was added to $200 \mathrm{~mL}$ of $5 \mathrm{mg} / \mathrm{L} \mathrm{RhB}$ aqueous solution, and the mixture was stirred for $30 \mathrm{~min}$ in the dark to achieve adsorption-desorption equilibrium between the dye and the catalyst. The experimental solution was placed $350 \mathrm{~mm}$ from the 500-W Xe lamp (with a $<400 \mathrm{~nm}$ UV cutoff filter). Samples were collected after every $0.5 \mathrm{~h}$ of irradiation, and then centrifuged $(10,000 \mathrm{r} / \mathrm{min})$ to remove the catalyst. Subsequently, the absorbance of the solution at $552 \mathrm{~nm}$ was measured to indicate the concentration of the remaining dye. For comparison, the photocatalytic experiments were conducted with Samples 7.5, 8.0, 8.5, and 9.0 as catalysts, and with no catalyst. 


\section{Results and Discussion}

\subsection{XRD Pattern Analysis}

When the synthesis reaction was performed in a $\mathrm{pH}$ solution of 7.5, the XRD diffraction pattern of the resulting sample was similar to that of monoclinic $\mathrm{BiVO}_{4}$ (yellow line in Figure 1 JCPDS\#83-1697) [25], indicating that the sample was monoclinic $\mathrm{BiVO}_{4}$. In contrast, the XRD diffraction peaks of samples 8.0 and 8.5 showed characteristics of both $\mathrm{BiVO}_{4}$ and $\mathrm{Bi}_{2} \mathrm{~S}_{3}$ (JCPDS\#84-0279) [26]. As the $\mathrm{pH}$ increased, the $\mathrm{Bi}_{2} \mathrm{~S}_{3}$ peak increased in both height and intensity. However, when the $\mathrm{pH}$ of the precursor solution was 9.0, only $\mathrm{Bi}_{2} \mathrm{~S}_{3}$ was obtained. Therefore, the SEM, XPS, and TEM results indicate that $\mathrm{Bi}_{2} \mathrm{~S}_{3} / \mathrm{BiVO}_{4}$ heterojunction may be synthesized when the reaction was performed under a $\mathrm{pH}$ of 8.0 or (and) 8.5 .

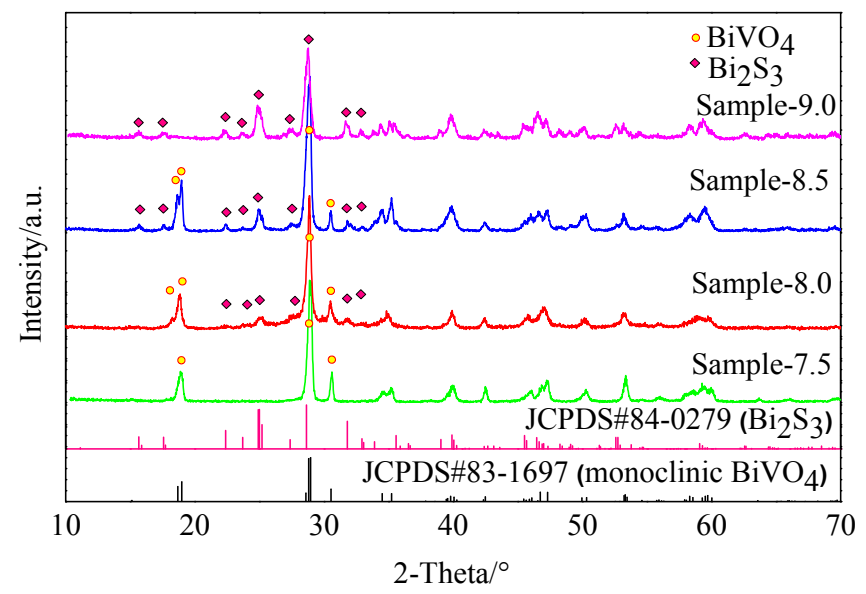

Figure 1. X-ray diffraction (XRD) patterns.

\subsection{Morphology Analysis Based on SEM, HRTEM, and FT-IR}

According to the SEM images (Figure 2), sample 7.5 was cube-like in shape, with a length of about $5 \mu \mathrm{m}$, whereas sample 8.0 consisted of concentric layers, with some $\mathrm{Bi}_{2} \mathrm{~S}_{3}$ particles dotting the outer layers. Sample 8.5 mainly consisted of $\mathrm{BiVO}_{4}$ shaped as hexagonal pyramids and some flakes of $\mathrm{Bi}_{2} \mathrm{~S}_{3}$. Sample 9.0 consisted of only $\mathrm{Bi}_{2} \mathrm{~S}_{3}$ flakes. Therefore, the $\mathrm{pH}$ of the precursor solution strongly influenced the prepared products. Characteristic stripes of $\mathrm{BiVO}_{4}(004)$ [27] and $\mathrm{Bi}_{2} \mathrm{~S}_{3}$ (200) [28] can be observed from the HRTEM results (Figure 2e). Figure $2 \mathrm{f}$ shows the FT-IR spectra of sample 8.0. The broad absorptions at $740 \mathrm{~cm}^{-1}$ can be attributed to $\mathrm{BiVO}_{4}$ [29]. Furthermore, absorption at $543 \mathrm{~cm}^{-1}$ and $486 \mathrm{~cm}^{-1}$ can be ascribed to $\mathrm{Bi}_{2} \mathrm{~S}_{3}$ [30], whereas the broad and weak peaks around $3700 \mathrm{~cm}^{-1}$ and $1600 \mathrm{~cm}^{-1}$ are due to the vibrational rotation and bending deformation of very small amounts of water molecules in the sample [31]. These results show that the heterojunction was successfully prepared when the $\mathrm{pH}$ of precursor solution was 8.0.

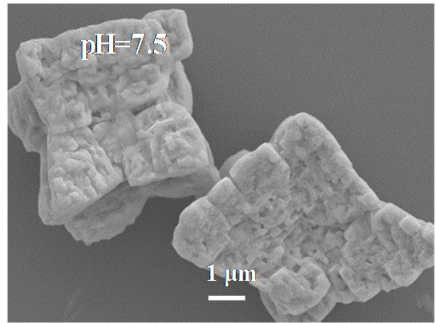

(a)

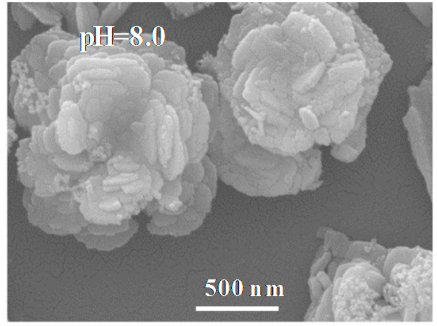

(b)

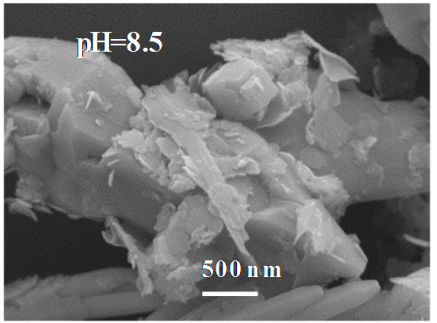

(c)

Figure 2. Cont. 


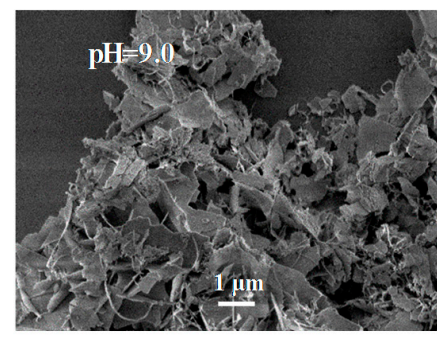

(d)

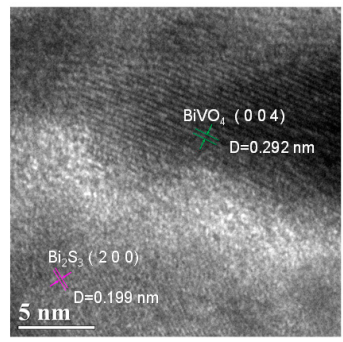

(e)

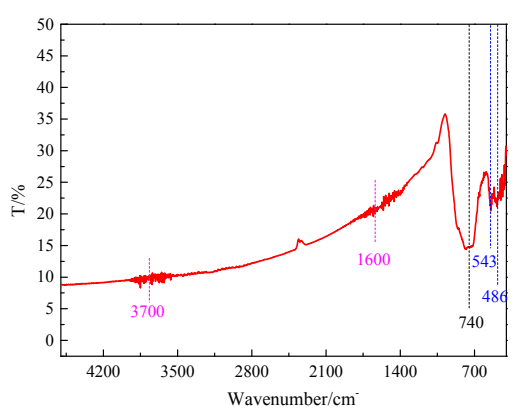

(f)

Figure 2. Scanning electron microscopy (SEM) (a-d) of samples, HRTEM (e) of Sample-8.0, and Fourier-transform infrared (FT-IR) spectra (f) of Sample-8.0.

\subsection{Analysis of Composition and Chemical States Based on EDX and XPS}

The composition and chemical states of samples were analyzed based on EDX and XPS. According to the EDX patterns of samples (Figure 3a), sample 7.5 contained the elements $\mathrm{C}, \mathrm{Bi}, \mathrm{O}$, and $\mathrm{V}$. When the $\mathrm{pH}$ of the precursor solution was 8.0 and 8.5 , the sample contained $\mathrm{C}, \mathrm{Bi}, \mathrm{O}, \mathrm{V}$, and $\mathrm{S}$. As the $\mathrm{pH}$ increased to 9.0 , only $\mathrm{C}, \mathrm{Bi}$, and $\mathrm{S}$ were tested. Carbon was mostly due to $\mathrm{CO}_{2}$ adsorption from the atmosphere [32], whereas $\mathrm{Si}$ was from the substrate. The wt $\%$ of $\mathrm{Bi}, \mathrm{V}, \mathrm{O}, \mathrm{S}$, and $\mathrm{C}$ in the samples tested via EDX are listed in Table 1, as well as the speculated composition. The molar ratio of $\mathrm{BiVO}_{4}: \mathrm{Bi}_{2} \mathrm{~S}_{3}$ was about 7.42:1 and 6.07:1 in samples 8.0 and 8.5 , respectively.

Table 1. Sample composition based on EDX.

\begin{tabular}{ccccccc}
\hline \multirow{2}{*}{ Sample } & $\mathbf{B i}$ & $\mathbf{V}$ & $\mathbf{O}$ & $\mathbf{S}$ & $\mathbf{C}$ & Molar Ratio \\
\cline { 2 - 7 } & wt \% & wt \% & wt \% & wt \% & wt \% & $\mathbf{B i V O}_{\mathbf{4}}: \mathbf{B i}_{\mathbf{2}} \mathbf{S}_{\mathbf{3}}$ \\
\hline Sample-7.5 & 61.36 & 15.89 & 18.94 & 0.00 & 3.81 & $/$ \\
Sample-8.0 & 76.04 & 14.50 & 2.26 & 3.69 & 3.51 & $7.42: 1$ \\
Sample-8.5 & 79.76 & 11.64 & 2.09 & 3.62 & 2.89 & $6.07: 1$ \\
Sample-9.0 & 78.75 & 0.00 & 0.00 & 17.67 & 3.58 & $/$ \\
\hline
\end{tabular}

The chemical state of Sample- 8 was analyzed by XPS. Figure $3 \mathrm{~b}$ shows fully scanned spectra and the $S 2 s$ orbital of Sample- 8.0 within the range of $0-700 \mathrm{eV}$. As shown in the spectra, the composite material was composed of $\mathrm{Bi}, \mathrm{O}, \mathrm{V}, \mathrm{C}$, and $\mathrm{S}$. The binding energy of $\mathrm{C}$ ls of the non-oxygenated ring $\mathrm{C}$ was corrected to $284.6 \mathrm{eV}$ (Figure 3c) [33]. The V $2 p$ core level spectrum in Figure $3 \mathrm{~d}$ indicates that the binding energies (516.8 and $524.4 \mathrm{eV}$ ) for $\mathrm{V} 2 p$ are in accordance with former reports on $\mathrm{V}^{5+}$ in $\mathrm{BiVO}_{4}$ [34]. The XPS signals of $\mathrm{O} 1 \mathrm{~s}$ are $529.7 \mathrm{eV}$ and $532.7 \mathrm{eV}$ (Figure 3e) [14], respectively; this can be explained by the existence of $\mathrm{O}_{2}{ }^{-}$anions in $\mathrm{BiVO}_{4}$. According to Figure $3 \mathrm{f}$, the peaks with binding energies of $159.3 \mathrm{eV}$ and $164.6 \mathrm{eV}$ are respectively related to $\mathrm{Bi} 4 f 7 / 2$ and $\mathrm{Bi} 4 f 5 / 2$ in $\mathrm{BiVO}_{4}$ [35]. The peaks with binding energies of $157.2 \mathrm{eV}$ and $162.6 \mathrm{eV}$ respectively correspond to Bi $4 f 7 / 2$ and $\mathrm{Bi} 4 f 5 / 2$ in $\mathrm{Bi}_{2} \mathrm{~S}_{3}$ [36]. The peak with binding energy of $160.4 \mathrm{eV}$ corresponds to the $\mathrm{S}$ $2 p$ transition [37]. It is known that the binding energy of pure $\mathrm{Bi}_{2} \mathrm{~S}_{3}$ is $158.9 \pm 0.1 \mathrm{eV}$, whereas the measured value is $158.4 \pm 0.1 \mathrm{eV}$ [38]. This shift indicates the interfacial chemical interaction between $\mathrm{Bi}_{2} \mathrm{~S}_{3}$ and $\mathrm{BiVO}_{4}$ [39]. In conclusion, the XRD, SEM, TEM, EDX, and XPS results indicate that $\mathrm{Bi}_{2} \mathrm{~S}_{3}$ quantum dots successfully formed on $\mathrm{BiVO}_{4}$. 


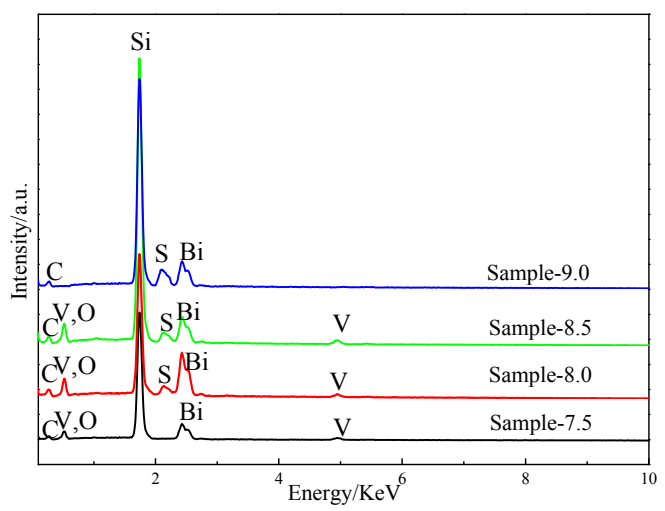

(a)

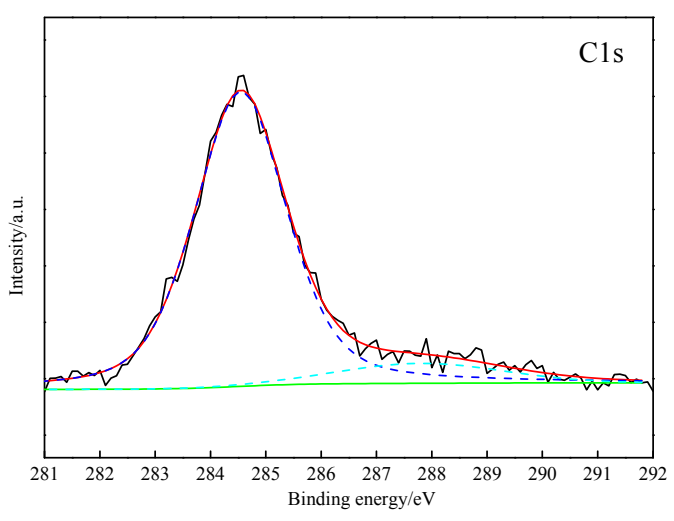

(c)

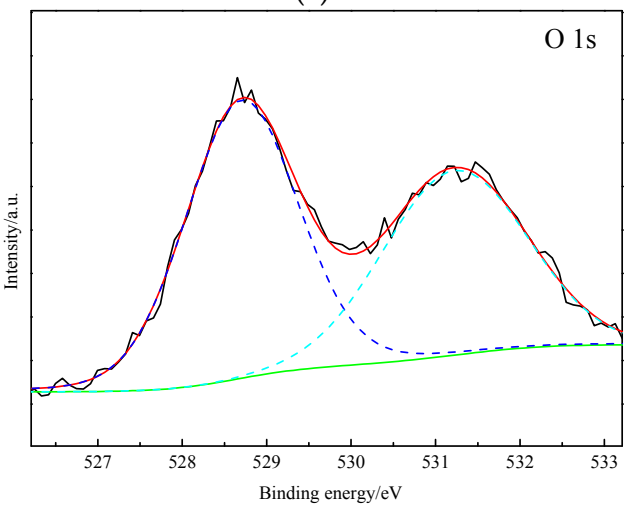

(e)

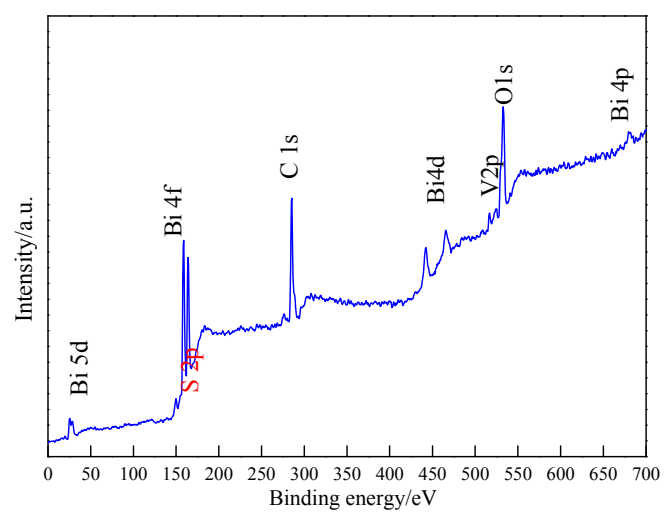

(b)

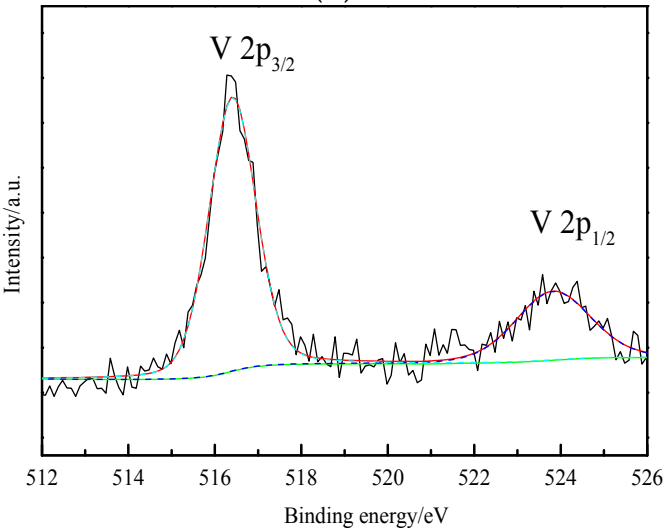

(d)

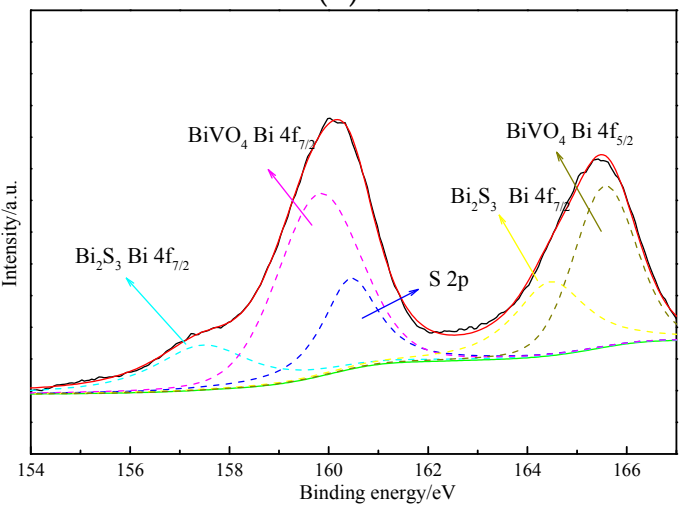

(f)

Figure 3. Energy dispersive $X$-ray detector (EDX) spectra of all samples (a) and X-ray photoelectron spectra (XPS) spectra of Sample-8.0 (b-f): (b) survey XPS spectrum, (c) C 1s peaks, (d) V 2p3/2 and V $2 p 1 / 2$ peaks, (e) O 1 s peak, and (f) Bi $4 f 5 / 2$, Bi $4 f 7 / 2$ and $S 2 p$ peaks.

\subsection{Optical Properties Characterized by UV-Vis DRS, Transient Photocurrent Response, and PL}

Both $\mathrm{BiVO}_{4}[40,41]$ and $\mathrm{Bi}_{2} \mathrm{~S}_{3}[22,42-44]$ display characteristics of direct transition. The light absorption properties and the band gap of the semiconductor can be determined based on UV-Vis absorption spectra (Figure 4a). Moreover, the band gap can be obtained from the slope of $(\mathrm{Ahv})^{2}$ versus hv using Equation (1):

$$
\begin{gathered}
\mathrm{Ah} v=\mathrm{C}\left(\mathrm{h} v-E_{g}\right)^{1 / 2} \\
E_{V B}=\chi-E_{e}+0.5 E_{g} \\
E_{C B}=E_{V B}-E_{g}
\end{gathered}
$$


where $\mathrm{A}$ is the absorption coefficient, $E_{g}$ is the band gap energy, h is Planck's constant, $v$ is the incident light frequency, and $\mathrm{C}$ is a constant.

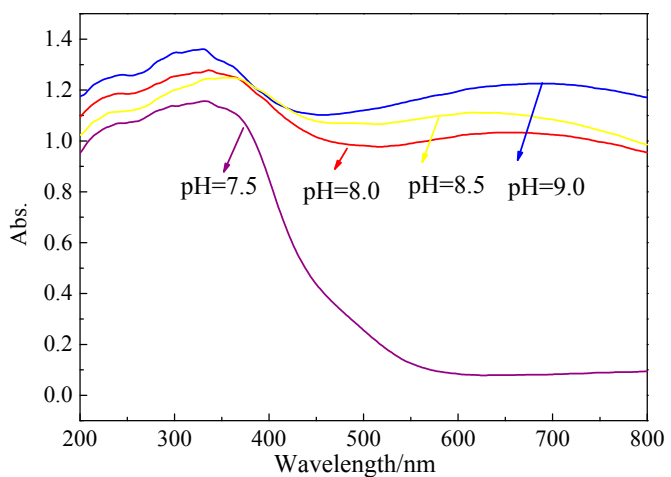

(a)

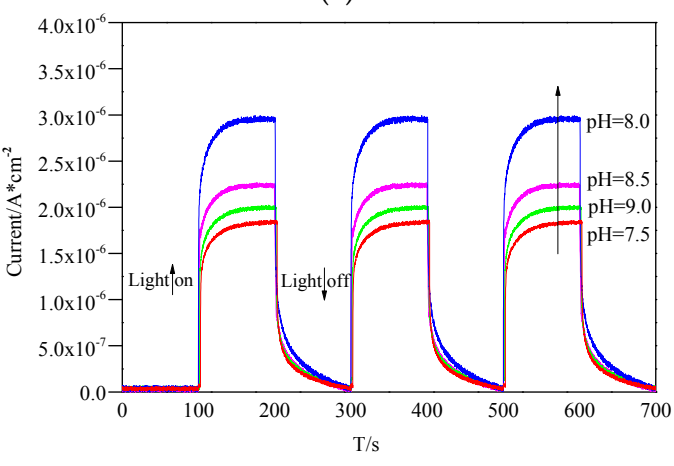

(c)

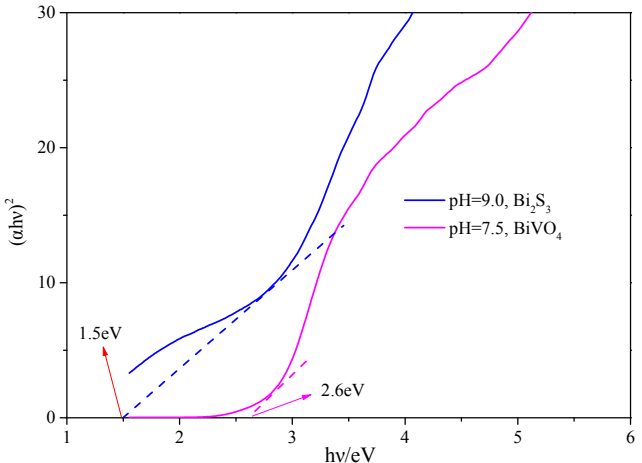

(b)

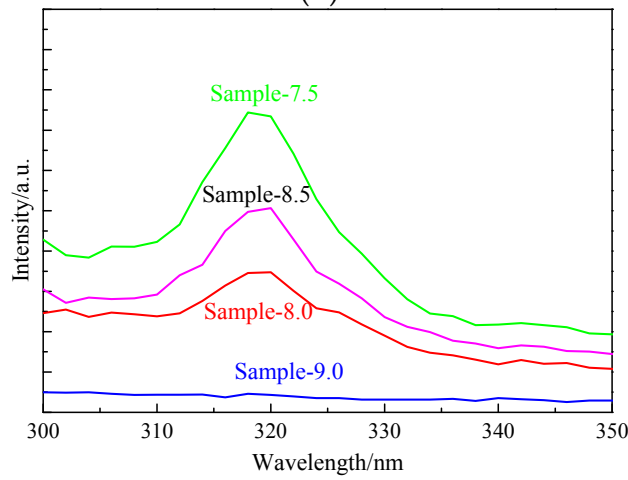

(d)

Figure 4. (a) UV-Vis diffuse reflectance spectra of samples; (b) Estimated band gaps of UV-Vis spectra of the samples; (c) Transient photocurrent response; (d) Photoluminescence (PL) spectra at an excitation wavelength of $280 \mathrm{~nm}$.

According to Figure $4 \mathrm{~b}$, sample 7.5 contained $\mathrm{BiVO}_{4}$. Most of the absorption regions were concentrated in the ultraviolet region, with a few concentrated in the visible region, and the band gap was $2.6 \mathrm{eV}$. Sample 9.0 contained $\mathrm{Bi}_{2} \mathrm{~S}_{3}$, and the spectra show almost complete absorption, with a band gap of about $1.5 \mathrm{eV}$. Based on Equations (2) and (3), the $\mathrm{VB}$ values of $\mathrm{Bi}_{2} \mathrm{~S}_{3}$ and $\mathrm{BiVO}_{4}$ are 1.52 and $2.84 \mathrm{eV}$, respectively, and the $\mathrm{CB}$ values of $\mathrm{Bi}_{2} \mathrm{~S}_{3}$ and $\mathrm{BiVO}_{4}$ are 0.02 and $0.24 \mathrm{eV}$, respectively. Thus, $\mathrm{Bi}_{2} \mathrm{~S}_{3}$ enhanced the absorption of visible light by $\mathrm{BiVO}_{4}$.

Photoelectrochemical tests were conducted to analyze the excitation, separation, and transfer of carriers in the catalyst. Photoanodes were prepared by electrophoretic deposition on ITO glass supports. The electrophoretic deposition was carried out in an acetone solution (20 $\mathrm{mL})$ containing iodine $(50 \mathrm{mg})$ and photocatalyst powder $(50 \mathrm{mg})$, and then dispersed via sonication for $5 \mathrm{~min}$. The ITO electrode $\left(1.0 \times 2.0 \mathrm{~cm}^{2}\right.$ was immersed in the solution with a Pt electrode, and a $30 \mathrm{~V}$ differential was applied for $100 \mathrm{~s}$ using a potentiostat. After this process was repeated twenty times, the electrode was dried and calcined at $200{ }^{\circ} \mathrm{C}$ for $2 \mathrm{~h}$. The exposed effective area of the ITO glass was controlled to be $1.0 \times 1.0 \mathrm{~cm}^{2}$. According to the transient photocurrent responses of the samples under visible irradiation (Figure 4c), the photocurrent of sample 8.0 had the highest density, followed by sample 8.5, sample 9.0, and finally sample 7.5. The PL spectra (excitation wavelength of $280 \mathrm{~nm}$ ) are shown in Figure 4d. The characteristic peak of bismuth vanadate is visible at $320 \mathrm{~nm}$ [45]. No peak was visible in sample 9.0 owing to the presence of bismuth sulfide. In contrast, sample 7.5 had the strongest peak, followed by sample 8.5 , and sample 8.0. This is because sample 8.0 contained a $\mathrm{Bi}_{2} \mathrm{~S}_{3} / \mathrm{BiVO}_{4}$ heterojunction, which is conductive to the separation of electron-hole pairs. Sample 8.5 was produced by physical contact of $\mathrm{Bi}_{2} \mathrm{~S}_{3}$ and $\mathrm{BiVO}_{4}$. Sample 9.0 contained $\mathrm{Bi}_{2} \mathrm{~S}_{3}$, but even though this catalyst can 
almost completely absorb visible light, the recombination of electrons and holes may occur due to the narrow band gap. Sample 7.5 contained $\mathrm{BiVO}_{4}$, which has a limited visible absorption range. Therefore, sample 8.0 displays the strongest potential for use in photoelectric and environmental applications.

\subsection{Evaluation of Photocatalytic Activity Based on RhB Degradation}

Figure 5a shows the results of the adsorption-desorption equilibrium tests. The samples were collected once every 5 min during the dark reaction stage. The RhB concentrations of the various solutions stabilized over time. Dyes and catalysts reached adsorption-desorption equilibrium after stirring for $30 \mathrm{~min}$ in the dark. Figure $5 \mathrm{~b}$ shows the photocatalytic activities of the samples under visible irradiation for $3 \mathrm{~h}$, and the corresponding degradation kinetics constants are shown in Figure 5c. For comparison, the $\mathrm{RhB}$ degradation rate was also estimated with no catalyst. The results indicate that $45.07 \%, 62.13 \%, 72.00 \%$, and $100.00 \%$ of the $\mathrm{RhB}$ was degraded when samples $9.0,7.5,8.5$, and 8.0 were used as catalysts, respectively. This indicates that sample 8.0 has the highest catalytic activity, followed by sample 8.5 , sample 7.5, and sample 9.0. Sample 8.0 can be easily recycled by simple filtration, and its degradation effect was respectively maintained at 95.19\%, 95.18\%, 94.91\%, 94.64\%, and 94.63\% after five recycling cycles (Figure $5 \mathrm{~d}$ ). The EDX, SEM, and XRD results for sample 8.0 after five recycling cycles indicated that no leaching of elements occurred and the morphology remained unchanged (Figure 5e,f). This indicated that sample 8.0 has an excellent heterostructure. Furthermore, the $\mathrm{Bi}_{2} \mathrm{~S}_{3}$ dots were very small $(19.7 \pm 2.2 \mathrm{~nm}$, calculated based on the Sherer relation); thus, the specific surface area of the sample was larger than that of pure $\mathrm{BiVO}_{4}$ (Table 2). The specific surface area of samples $7.5,8.0,8.5$, and 9.0 was $6.423,19.527,12.642$, and $21.165 \mathrm{~m}^{2} \mathrm{~g}^{-1}$, respectively, indicating that $\mathrm{Bi}_{2} \mathrm{~S}_{3}$ greatly impacted the specific surface area of the samples. The formation of the heterojunction, and the greater specific surface area of $\mathrm{BiVO}_{4}$ of sample 8.0 improved its photocatalytic activity. These features are very important for its practical application and modification.

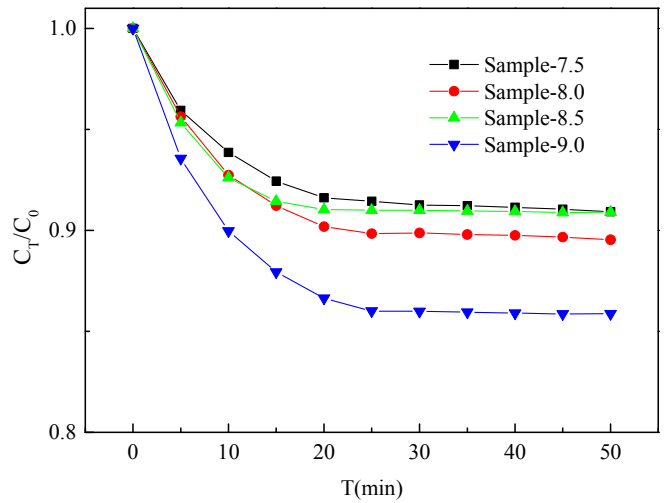

(a)

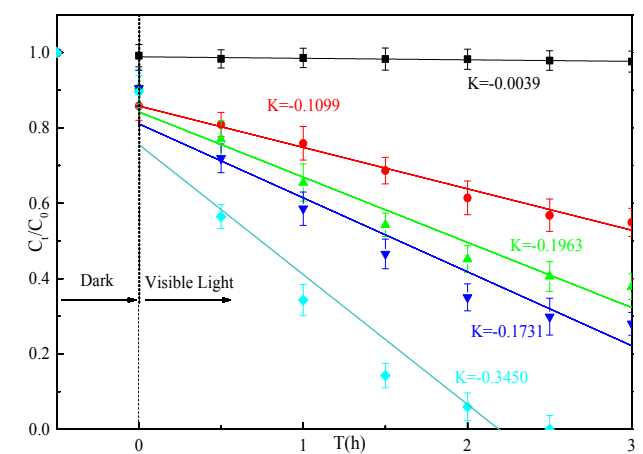

(c)

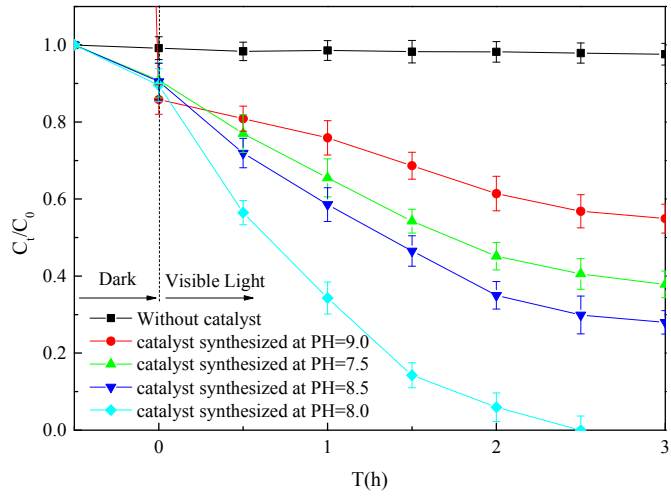

(b)

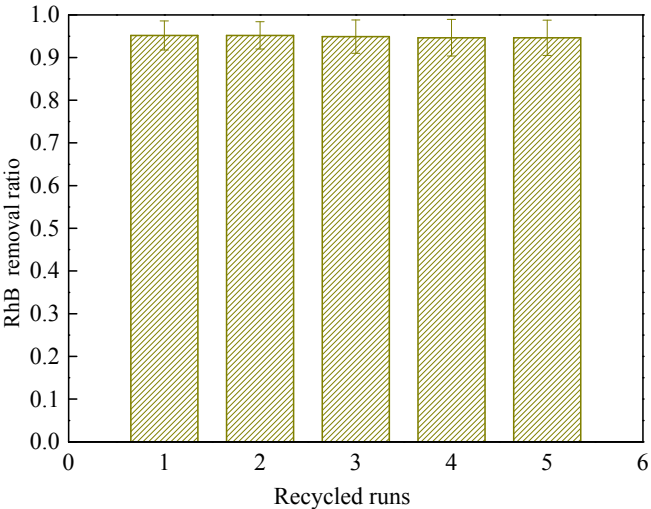

(d)

Figure 5. Cont. 


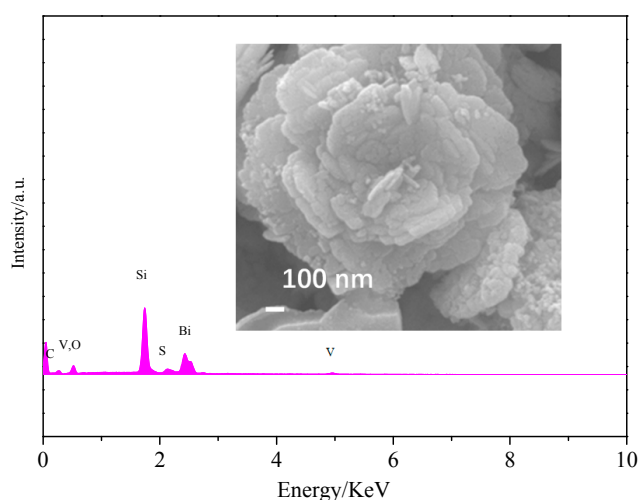

(e)

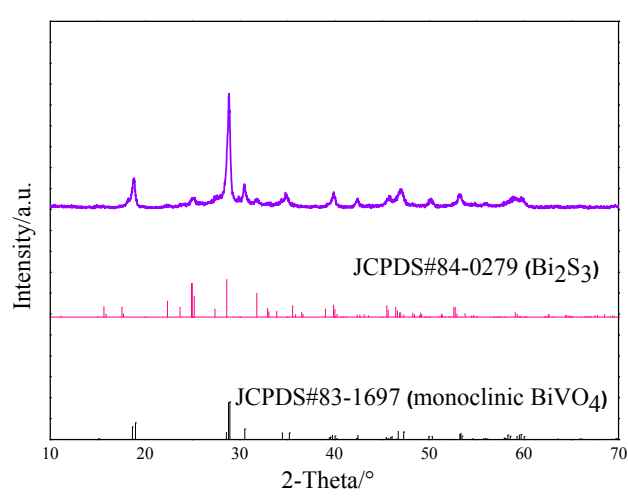

(f)

Figure 5. (a) Adsorption-desorption equilibrium test results; (b) Degradation of rhodamine B (RhB) using different catalysts under visible light irradiation; (c) Linear fit of the photocatalytic reaction and the reaction rate constant k; (d) Photocatalytic degradation of RhB reusing photocatalyst sample 8 after filtration; (e) EDX and SEM (inset) of sample 8 after recycling five times; (f) XRD of sample 8 after recycling five times.

Table 2. Brunner-Emmet-Teller (BET) measurements of samples.

\begin{tabular}{cccc}
\hline Sample & Mean Pore Size $(\mathbf{n m})$ & Pore Volume $\left(\mathbf{c m}^{\mathbf{3}} \mathbf{g}^{-\mathbf{1}}\right)$ & Specific Surface Area $\left(\mathbf{m}^{\mathbf{2}} \mathbf{g}^{-\mathbf{1}}\right)$ \\
\hline Sample-7.5 & 15.765 & 0.024 & 6.423 \\
Sample-8.0 & 15.462 & 0.021 & 19.527 \\
Sample-8.5 & 14.459 & 0.018 & 12.642 \\
Sample-9.0 & 17.265 & 0.030 & 21.165 \\
\hline
\end{tabular}

\subsection{Postulated Heterojunction Formation Mechanism}

The $\mathrm{pH}$ of the reaction system had a strong influence on the crystal phase and morphology of the synthesized products [46]. By fixing the amounts of materials and L-cysteine, as well as the reaction parameters (except $\mathrm{pH}$ ), the synthesis reaction was conducted under varying $\mathrm{pH}$ values. To explain the results, we speculated a series of reactions that can occur successively based on the amount of $\mathrm{OH}^{-}$. First, when $\mathrm{Bi}^{3+}$ is added to the $\mathrm{L}$-cysteine system, chelation between the metal and amino acids can occur (4) [47].

$$
\mathrm{Bi}^{3+}+\mathrm{nL}-\text { cysteine } \rightarrow[\mathrm{Bi}(\mathrm{L}-\text { cysteine }) \mathrm{n}]^{3+}
$$

Below, we discuss what happens when the $\mathrm{pH}$ of different systems is adjusted.

The $\mathrm{pH}$ was lowest in the first system. Pure monoclinic $\mathrm{BiVO}_{4}$ was produced. The probably reaction is the (5), because we know that $\mathrm{S}^{3-}$ did not exist in the system and $\mathrm{S}^{3-}$ can exchange ions with $\mathrm{BiVO}_{4}$ to form $\mathrm{Bi}_{2} \mathrm{~S}_{3}$ [32].

$$
[\mathrm{Bi}(\mathrm{L}-\text { cysteine }) \mathrm{n}]^{3+}+\mathrm{VO}_{3}^{-}+\mathrm{H}^{+} \rightarrow \mathrm{BiVO}_{4} \downarrow+\mathrm{H}_{2} \mathrm{~S} \uparrow+\mathrm{H}_{2} \mathrm{O}
$$

In the second system, the $\mathrm{pH}$ was adjusted to 8.0 , and the composite $\mathrm{Bi}_{2} \mathrm{~S}_{3} / \mathrm{BiVO}_{4}$ was produced. We can see that some $\mathrm{Bi}_{2} \mathrm{~S}_{3}$ formed on the $\mathrm{BiVO}_{4}$; thus, we speculate that (5) still took place in the system. Since $\mathrm{OH}^{-}$remains in the system, (6) will occur, forming $\mathrm{S}^{2-}$. Then, as previously mentioned, $\mathrm{S}^{2-}$ will react with $\mathrm{BiVO}_{4}$ to form $\mathrm{Bi}_{2} \mathrm{~S}_{3}$. As the amount of $\mathrm{S}$ in the system was low (0.6 mmol in total), some of the $\mathrm{BiVO}_{4}$ formed $\mathrm{Bi}_{2} \mathrm{~S}_{3}$ as shown in Figure $2 \mathrm{~b}$.

$$
\begin{gathered}
\mathrm{H}_{2} \mathrm{~S}+\mathrm{OH}^{-} \rightarrow \mathrm{S}^{2-}+\mathrm{H}_{2} \mathrm{O} \\
\mathrm{BiVO}_{4}+\mathrm{S}^{2-} \rightarrow \mathrm{Bi}_{2} \mathrm{~S}_{3} \downarrow+\mathrm{VO}_{4}^{+}
\end{gathered}
$$


As the $\mathrm{pH}$ increased to 8.5 , the first reaction could no longer take place. Instead, (8) occurred, causing the $\mathrm{OH}^{-}$concentration to decrease, followed by (9). Sample 8.5 consisted of both $\mathrm{Bi}_{2} \mathrm{~S}_{3}$ and $\mathrm{BiVO}_{4}$, separately.

$$
\begin{gathered}
{[\mathrm{Bi}(\mathrm{L}-\text { cysteine }) \mathrm{n}]^{3+}+\mathrm{NH}_{4}^{+}+\mathrm{OH}^{-} \rightarrow \mathrm{Bi}_{2} \mathrm{~S}_{3} \downarrow+\mathrm{NH}_{3} \uparrow+\mathrm{H}_{2} \mathrm{O}} \\
\mathrm{Bi}^{3+}+\mathrm{VO}_{3}^{-} \rightarrow \mathrm{BiVO}_{4} \downarrow
\end{gathered}
$$

Equation (8) could still take place under a $\mathrm{pH}$ of 9.0. The synthesized sample contained only $\mathrm{Bi}_{2} \mathrm{~S}_{3}$ due to the high $\mathrm{OH}^{-}$concentration. The remaining $\mathrm{Bi}^{3+}$ first reacted with $\mathrm{OH}^{-}$to form $\mathrm{Bi}(\mathrm{OH})_{3}$, as shown in (10). The reaction then continued, causing $\mathrm{Bi}(\mathrm{OH})_{3}$ to dissolve, and forming $\mathrm{Bi}(\mathrm{OH})_{4}^{-}(11)[48]$.

$$
\begin{gathered}
\mathrm{Bi}^{3+}+\mathrm{OH}^{-} \rightarrow \mathrm{Bi}(\mathrm{OH})_{3} \downarrow \\
\mathrm{Bi}(\mathrm{OH})_{3}+\mathrm{OH}^{-} \rightarrow \mathrm{Bi}(\mathrm{OH})_{4}^{-}
\end{gathered}
$$

\subsection{Postulated Degradation Mechanism}

Active species such as $\cdot \mathrm{O}_{2}{ }^{-}, \cdot \mathrm{OH}, \mathrm{e}^{-}$, and holes $\left(\mathrm{h}^{+}\right)$play an important role in the photodegradation of dyes [49]. To investigate the photocatalytic mechanism and activity of $\mathrm{Bi}_{2} \mathrm{~S}_{3} / \mathrm{BiVO}_{4}$, the contribution of each active species to the photodegradation performance was examined based on a scavenger experiment [50]. In this experiment, potassium sodium tartrate $\left(\mathrm{C}_{4} \mathrm{H}_{4} \mathrm{O}_{6} \mathrm{KNa} \cdot 4 \mathrm{H}_{2} \mathrm{O}, 0.1 \mathrm{mmol}\right)$ was used as the $\mathrm{h}^{+}$scavenger, silver nitrate $\left(\mathrm{AgNO}_{3}, 0.1 \mathrm{mmol}\right)$ was used as the $\mathrm{e}^{-}$scavenger, p-benzoquinone (PBQ, $0.1 \mathrm{mmol}$ ) was used as the $\cdot \mathrm{O}_{2}{ }^{-}$scavenger, and isopropanol (IPA, $0.1 \mathrm{mmol}$ ) was used as the $\cdot \mathrm{OH}$ scavenger. These scavengers were added to RhB solutions containing $\mathrm{Bi}_{2} \mathrm{~S}_{3} / \mathrm{BiVO}_{4}$, and the solutions were irradiated with visible light for $1.5 \mathrm{~h}$. According to Figure 6 , the addition of the $\mathrm{h}^{+}$scavenger $\left(\mathrm{C}_{4} \mathrm{H}_{4} \mathrm{O}_{6} \mathrm{KNa}\right)$ and the $\cdot \mathrm{O}_{2}{ }^{-}$scavenger (IPA) severely suppressed the catalytic performance, suggesting that $\mathrm{h}^{+}$and $\mathrm{O}_{2}{ }^{-}$are the main reactive species contributing to the photodegradation of $\mathrm{RhB}$. After the addition of the $\cdot \mathrm{OH}$ scavenger (IPA), the catalytic degradation effect was slightly inhibited, which suggests that $\cdot \mathrm{OH}$ plays an insignificant role in this reaction system. The $\cdot \mathrm{OH}$ was mainly produced by oxidation of $\mathrm{H}_{2} \mathrm{O}$ to $\cdot \mathrm{O}_{2}{ }^{-}$and $\mathrm{OH}^{-}$through $\mathrm{BiVO}_{4} \mathrm{VB}$ [1]. Lizhen Ren et al. reported that the $\mathrm{VB}$ of $\mathrm{Bi}_{2} \mathrm{~S}_{3}$ was not sufficient to oxidize $\mathrm{OH}^{-}$to $\cdot \mathrm{OH}$ [51]. After adding the $\mathrm{e}^{-}$scavenger $\left(\mathrm{AgNO}_{3}\right)$, the degradation efficiency increased owing to $\mathrm{e}^{-}$consumption and increased $\mathrm{h}^{+}$efficiency; therefore, $\mathrm{h}^{+}$plays the most important role in this degradation process and can directly degrade dyes $[1,49]$.

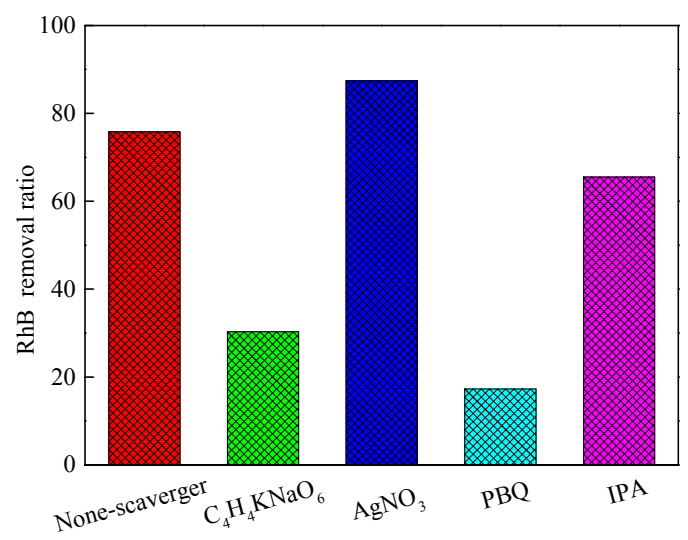

Figure 6. Scavenger effect of sample 8 photocatalyst.

The scavenger experiments confirmed the existence of $\cdot \mathrm{O}_{2}{ }^{-}, \cdot \mathrm{OH}, \mathrm{e}^{-}$, and $\mathrm{h}^{+}$in the catalytic system. A thorough understanding of the photocatalytic degradation mechanism is necessary for the actual application of $\mathrm{Bi}_{2} \mathrm{~S}_{3} / \mathrm{BiVO}_{4}$ heterojunctions. The postulated degradation mechanism is 
shown in . Figure 5a demonstrates that the concentration of the dye did not significantly change without the addition of a catalyst. In contrast, photocatalyst addition significantly reduced the dye concentration. The adsorption of dye onto the catalyst surface is the primary process, as shown in (12). RhB is sensitive to visible light, as indicated by (13) [52]. The potential energy of the RhB LUMO and $\mathrm{HOMO}$ was -1.42 and $0.95 \mathrm{eV}$, respectively [53]. The VB values of $\mathrm{Bi}_{2} \mathrm{~S}_{3}$ and $\mathrm{BiVO}_{4}$ were 1.52 and $2.84 \mathrm{eV}$, respectively, and the $\mathrm{CB}$ values of $\mathrm{Bi}_{2} \mathrm{~S}_{3}$ and $\mathrm{BiVO}_{4}$ were 0.02 and $0.24 \mathrm{eV}$, respectively. Hence, the photosensitive dye transferred electrons to the CB of semiconductors (14) [54]. $\mathrm{BiVO}_{4}$ and $\mathrm{Bi}_{2} \mathrm{~S}_{3}$ were excited under visible radiation, causing transfer of $\mathrm{Bi}_{2} \mathrm{~S}_{3}$ and $\mathrm{BiVO}_{4}$ electrons from $\mathrm{VB}$ to $\mathrm{CB}$, and leaving holes in $\mathrm{VB}((15)$ and (16)). Due to the formation of the heterojunction, the holes in the $\mathrm{VB}$ of $\mathrm{BiVO}_{4}$ shifted to the $\mathrm{VB}$ of $\mathrm{Bi}_{2} \mathrm{~S}_{3}$, while the electrons in $\mathrm{CB}$ of $\mathrm{Bi}_{2} \mathrm{~S}_{3}$ shifted to the $\mathrm{CB}$ of $\mathrm{BiVO}_{4}$. Thus, the carriers of the electron-hole pair were separated ((17) and (18)). $\mathrm{H}_{2} \mathrm{O}$ can ionize $\mathrm{OH}$, as shown (19). The photogenerated electrons can react with dissolved oxygen molecules $\left(\mathrm{O}_{2}\right)$ to yield superoxide radical anions $\left(\cdot \mathrm{O}_{2}{ }^{-}\right)$, as shown in (20), and $\cdot \mathrm{O}_{2}{ }^{-}$can react with $\mathrm{H}_{2} \mathrm{O}$ to produce $\cdot \mathrm{OH}$ (21) $[55,56]$. As previously mentioned, the $\mathrm{VB}$ of $\mathrm{BiVO}_{4}$ can oxidize $\mathrm{OH}^{-}$to $\cdot \mathrm{OH}(22)$, and $\mathrm{h}^{+}, \cdot \mathrm{O}_{2}{ }^{-}$, and $\cdot \mathrm{OH}$ are strong oxidizing agents for the decomposition of organic dyes (23) [57]. The whole set of redox reactions can be summarized as follows:

$$
\begin{gathered}
\mathrm{BiVO}_{4} / \mathrm{Bi}_{2} \mathrm{~S}_{3}+\mathrm{RhB} \rightarrow \text { adsorption } \\
\mathrm{RhB}+\mathrm{h} v \rightarrow \mathrm{RhB}^{*} \\
\mathrm{RhB}^{*}+\mathrm{BiVO}_{4} / \mathrm{Bi}_{2} \mathrm{~S}_{3} \rightarrow \mathrm{BiVO}_{4} / \mathrm{Bi}_{2} \mathrm{~S}_{3}\left(\mathrm{e}^{-}\right)+\mathrm{RhB}^{+} \\
\mathrm{Bi}_{2} \mathrm{~S}_{3}+\mathrm{h} v \rightarrow \mathrm{Bi}_{2} \mathrm{~S}_{3}\left(\mathrm{~h}^{+}\right)+\mathrm{Bi}_{2} \mathrm{~S}_{3}\left(\mathrm{e}^{-}\right) \\
\mathrm{BiVO}_{4}+\mathrm{h} v \rightarrow \mathrm{BiVO}_{4}\left(\mathrm{~h}^{+}\right)+\mathrm{BiVO}_{4}\left(\mathrm{e}^{-}\right) \\
\mathrm{Bi}_{2} \mathrm{~S}_{3}\left(\mathrm{e}^{-}\right)+\mathrm{BiVO}_{4} \rightarrow \mathrm{BiVO}_{4}\left(\mathrm{e}^{-}\right) \\
\mathrm{BiVO}_{4}\left(\mathrm{~h}^{+}\right)+\mathrm{Bi}_{2} \mathrm{~S}_{3} \rightarrow \mathrm{Bi}_{2} \mathrm{~S}_{3}\left(\mathrm{~h}^{+}\right) \\
\mathrm{H}_{2} \mathrm{O} \rightarrow \mathrm{H}^{+}+\mathrm{OH}^{-} \\
\left(\mathrm{e}^{-}\right)+\mathrm{O}_{2} \rightarrow \cdot \mathrm{O}_{2}- \\
\mathrm{H}_{2} \mathrm{O}+\cdot \mathrm{O}_{2}-\rightarrow \cdot \mathrm{OH}^{-}+\mathrm{OH}^{-}+\mathrm{O}_{2} \\
\mathrm{BiVO}{ }_{4}\left(\mathrm{~h}^{+}\right)+\mathrm{OH}^{-} \rightarrow \cdot \text { OH } \\
\left(\mathrm{h}^{+}\right) \text {or } \cdot \mathrm{O}_{2}-\text { or } \cdot \mathrm{OH}+\mathrm{RhB}^{-} \mathrm{RhB}^{+} \rightarrow \text { degradation products }
\end{gathered}
$$

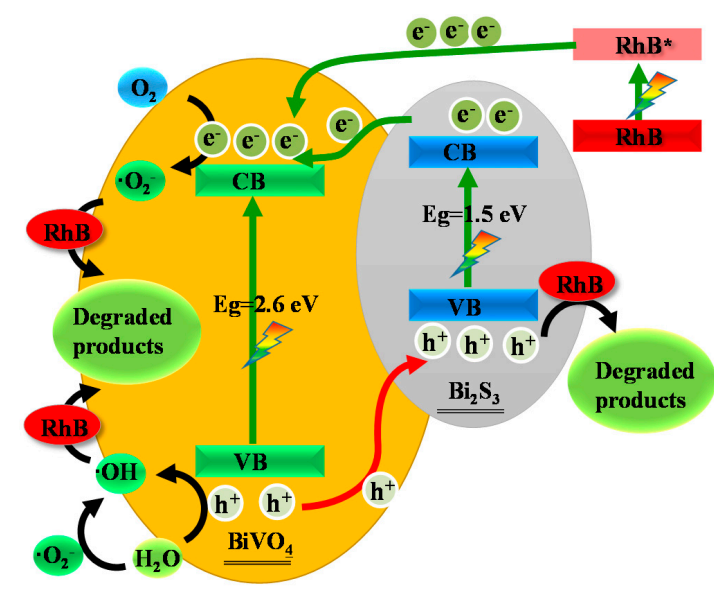

Schematic 1. Postulated mechanism for RhB degradation catalyzed with sample 8.0. 


\section{Conclusions}

A one-step method for synthesizing a $\mathrm{Bi}_{2} \mathrm{~S}_{3} / \mathrm{BiVO}_{4}$ heterojunction with high photocatalytic activity under visible irradiation was developed based on $\mathrm{pH}$ regulation of the reaction solution. The morphologies and compositions of prepared samples were characterized with various analytical methods. The degradation rate of $\mathrm{RhB}$ under visible irradiation was used to estimate the photocatalytic activity of prepared samples. The photocatalytic activity of sample 8.0 was higher than that of samples $7.5,8.5$, and 9.0 , because the former contained a heterojunction.

Acknowledgments: This work was supported by the Science and Technology Innovation Special Projects of Social Undertakings and Livelihood Support, Chongqing (cstc2016shmszx20009), the graduate scientific research and innovation foundation of Chongqing, China (CYB16008), the Chongqing Research Program of Basic Research and Frontier Technology (cstc2015jcyjA20013, cstc2017jcyjBX0080), and the 111 Project (B13041).

Author Contributions: Project conception/design: Deqiang Zhao, Fangying Ji and Xuan Xu; Performed the experiments: Wenjuan Zong, Shimin Xiong, Qian Zhang, and Wenwen Wang; Data analysis: Deqiang Zhao and Fangying Ji; Manuscript preparation: Deqiang Zhao and Xuan Xu. Authors have no competing financial interests.

Conflicts of Interest: Fangying Ji received research grants from the 111 Project (B13041). Xuan Xu received research grants from the Science and Technology Innovation Special Projects of Social Undertakings and Livelihood Support, Chongqing (cstc2016shmszx20009), and the 111 Project (B13041). Deqiang Zhao received research grants from the Graduate Scientific Research and Innovation Foundation of Chongqing, China (CYB16008). Wenjuan Zong, Shimin Xiong, Wenwen Wang, and Qian Zhang declare that they have no conflict of interest.

\section{References}

1. Jiang, Y.R.; Chou, S.Y.; Chang, J.L.; Huang, S.T.; Lin, H.P.; Chen, C.C. Hydrothermal synthesis of bismuth oxybromide-bismuth oxyiodide composites with high visible light photocatalytic performance for the degradation of CV and phenol. RSC Adv. 2015, 5, 30851-30860. [CrossRef]

2. Jiang, Y.R.; Lee, W.W.; Chen, K.T.; Wang, M.C.; Chang, K.H.; Chen, C.C. Hydrothermal synthesis of $\beta-\mathrm{ZnMoO}_{4}$ crystals and their photocatalytic degradation of Victoria Blue $\mathrm{R}$ and phenol. J. Taiwan Inst. Chem. Eng. 2014, 45, 207-218. [CrossRef]

3. Zubair, H.; Sung Hwa, J. Removal of hazardous organics from water using metal-organic frameworks (MOFs): Plausible mechanisms for selective adsorptions. J. Hazard. Mater. 2015, 283, 329-339.

4. Chou, S.Y.; Chung, W.H.; Chen, L.W.; Dai, Y.M.; Lin, W.Y.; Lin, J.H.; Chen, C.C. A series of BiOxIy/GO photocatalysts: Synthesis, characterization, activity, and mechanism. RSC Adv. 2016, 6, 82743-82758. [CrossRef]

5. Lee, W.W.; Lu, C.S.; Chuang, C.W.; Chen, Y.J.; Fu, J.Y.; Siao, C.W.; Chen, C.C. Synthesis of Bismuth Oxyiodides and Their Composites: Characterization, Photocatalytic Activity, and Degraded Mechanisms. RSC Adv. 2015, 5, 23450-23463. [CrossRef]

6. Chou, S.Y.; Chen, C.C.; Chen, L.W.; Dai, Y.M.; Lin, J.H.; Lee, W.W. Novel synthesis of bismuth oxyiodide/graphitic carbon nitride nanocomposite with enhanced visible-light photocatalytic activity. RSC Adv. 2016, 6, 33478-33491. [CrossRef]

7. Lee, Y.H.; Dai, Y.M.; Fu, J.Y.; Chen, C.C. A series of bismuth-oxychloride/bismuth-oxyiodide/graphene-oxide nanocomposites: Synthesis, characterization, and photcatalytic activity and mechanism. Mol. Catal. 2017, 432, 196-209. [CrossRef]

8. Liu, S.; Tang, H.; Zhou, H.; Dai, G.; Wang, W. Photocatalytic perfermance of sandwich-like $\mathrm{BiVO}_{4}$ sheets by microwave assisted synthesis. Appl. Surf. Sci. 2016, 391, 542-547. [CrossRef]

9. Xiao, B.C.; Lin, L.Y.; Hong, J.Y.; Lin, H.S.; Song, Y.T. Synthesis of a monoclinic $\mathrm{BiVO}_{4}$ nanorod array as the photocatalyst for efficient photoelectrochemical water oxidation. RSC Adv. 2017, 7, 7547-7554. [CrossRef]

10. Lee, C.K.; Ong, C.S. Synthesis and characterisation of rare earth substituted bismuth vanadate solid electrolytes. Solid State Ion. 1999, 117, 301-310. [CrossRef]

11. Zhang, A.; Zhang, J. Effects of europium doping on the photocatalytic behavior of $\mathrm{BiVO}_{4}$. J. Hazard. Mater. 2010, 173, 265-272. [CrossRef] [PubMed]

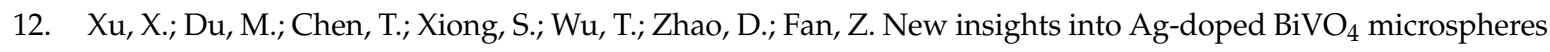
as visible light photocatalysts. RSC Adv. 2016, 6, 98788-98796. [CrossRef] 
13. Lei, G. Novel Pd/BiVO 4 composite photocatalysts for efficient degradation of methyl orange under visible light irradiation. Mater. Chem. Phys. 2008, 107, 465-470.

14. Zhao, D.; Zong, W.; Fan, Z.; Xiong, S.; Du, M.; Wu, T.; Fang, Y.W.; Ji, F.; Xu, X. Synthesis of Carbon Doped $\mathrm{BiVO}_{4} @$ Multi-walled Carbon Nanotubes with High Visible Light Absorption Behavior and Evaluation of Its Photocatalytic Property. CrystEngComm 2016, 18, 9007-9015. [CrossRef]

15. Yin, C.; Zhu, S.; Chen, Z.; Zhang, W.; Gu, J.; Zhang, D. One step fabrication of C-doped BiVO 4 with hierarchical structures for a high-performance photocatalyst under visible light irradiation. J. Mater. Chem. A 2013, 1, 8367-8378. [CrossRef]

16. Su, J.; Guo, L.; Bao, N.; Grimes, C.A. Nanostructured $\mathrm{WO}_{3} / \mathrm{BiVO}_{4}$ Heterojunction Films for Efficient Photoelectrochemical Water Splitting. Nano Lett. 2011, 11, 1928-1933. [CrossRef] [PubMed]

17. Kim, E.S.; Kang, H.J.; Magesh, G.; Kim, J.Y.; Jang, J.W.; Lee, J.S. Improved photoelectrochemical activity of $\mathrm{CaFe}_{2} \mathrm{O}_{4} / \mathrm{BiVO}_{4}$ heterojunction photoanode by reduced surface recombination in solar water oxidation. ACS Appl. Mater. Interfaces 2014, 6, 17762-17769. [CrossRef] [PubMed]

18. He, Z.; Shi, Y.; Gao, C.; Wen, L.; Chen, J.; Song, S. BiOCl/BiVO 4 p-n Heterojunction with Enhanced Photocatalytic Activity under Visible-Light Irradiation. J. Phys. Chem. C 2013, 118, 389-398. [CrossRef]

19. Chang, X.; Wang, T.; Peng, Z.; Zhang, J.; Li, A.; Gong, J. Enhanced Surface Reaction Kinetics and Charge Separation of p-n Heterojunction $\mathrm{CO}_{3} \mathrm{O}_{4} / \mathrm{BiVO}_{4}$ Photoanodes. J. Am. Chem. Soc. 2015, 137, 8356-8359. [CrossRef] [PubMed]

20. Yu, H.; Wang, J.; Wang, T.; Yu, H.; Yang, J.; Liu, G.; Qiao, G.; Yang, Q.; Cheng, X. Scalable colloidal synthesis of uniform $\mathrm{Bi}_{2} \mathrm{~S}_{3}$ nanorods as sensitive materials for visible-light photodetectors. CrystEngComm 2017, 19, 727-733. [CrossRef]

21. Kumar, S.; Sharma, S.; Umar, A.; Kansal, S.K. Bismuth Sulphide $\left(\mathrm{Bi}_{2} \mathrm{~S}_{3}\right)$ Nanotubes as an Efficient Photocatalyst for Methylene Blue Dye Degradation. Nanosci. Nanotechnol. Lett. 2016, 8, 266-272. [CrossRef]

22. Ma, D.K.; Guan, M.L.; Liu, S.S.; Zhang, Y.Q.; Zhang, C.W.; He, Y.X.; Huang, S.M. Controlled synthesis of olive-shaped $\mathrm{Bi}_{2} \mathrm{~S}_{3} / \mathrm{BiVO}_{4}$ microspheres through a limited chemical conversion route and enhanced visible-light-responding photocatalytic activity. Dalton Trans. 2012, 41, 5581-5586. [CrossRef] [PubMed]

23. Liu, C.; Li, J.; Li, Y.; Li, W.; Yang, Y.; Chen, Q. Epitaxial growth of $\mathrm{Bi}_{2} \mathrm{~S}_{3}$ nanowires on $\mathrm{BiVO}_{4}$ nanostructures for enhancing photoelectrochemical performance. RSC Adv. 2015, 5, 71692-71698. [CrossRef]

24. Gao, X.; Wu, H.B.; Zheng, L.; Zhong, Y.; Hu, Y.; Lou, X.W. Formation of Mesoporous Heterostructured $\mathrm{BiVO}_{4} / \mathrm{Bi}_{2} \mathrm{~S}_{3}$ Hollow Discoids with Enhanced Photoactivity. Angew. Chem. 2014, 53, 5917-5921. [CrossRef] [PubMed]

25. Obregón, S.; Colón, G. On the different photocatalytic performance of $\mathrm{BiVO}_{4}$ catalysts for Methylene Blue and Rhodamine B degradation. J. Mol. Catal. A Chem. 2013, 376, 40-47. [CrossRef]

26. Zhou, X.; Ma, L.; Feng, Z. Synthesis and Characterization of Bismuth Sulfide Nanorods by Solvothermal Route. Chem. Lett. 2015, 44, 1113-1115. [CrossRef]

27. Zheng, Y.; Wu, J.; Duan, F.; Xie, Y. Gemini Surfactant Directed Preparation and Photocatalysis of $m-B^{2} \mathrm{BO}_{4}$ Hierarchical Frameworks. Chem. Lett. 2007, 36, 520-521. [CrossRef]

28. Zhang, H.; Ji, Y.; Ma, X.; Xu, J.; Yang, D. Long $\mathrm{Bi}_{2} \mathrm{~S}_{3}$ nanowires prepared by a simple hydrothermal method. Nanotechnology 2003, 14, 974-977. [CrossRef]

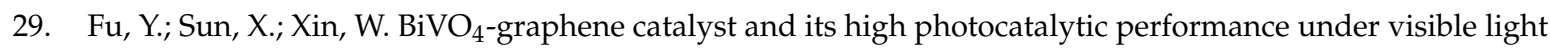
irradiation. Mater. Chem. Phys. 2011, 131, 325-330. [CrossRef]

30. Chu, W.; Tao, T.; Xu, J. Synthesis, characterization and photocatalytic property of BiOI/ $\mathrm{Bi}_{2} \mathrm{~S}_{3} / \mathrm{AOCF}$ composite. New Chem. Mater. 2016, 44, 237-239.

31. $\mathrm{Vu}, \mathrm{T} . \mathrm{H}$. Water-Guest Interactions under Clathrate Hydrate Formation Conditions: A Matrix-Isolation Approach. Ph.D. Thesis, Tufts University, Medford, MA, USA, 2013.

32. Malakooti, R.; Cademartiri, L.; Akçakir, Y.; Petrov, S.; Migliori, A.; Ozin, G.A. Shape-Controlled $\mathrm{Bi}_{2} \mathrm{~S}_{3}$ Nanocrystals and Their Plasma Polymerization into Flexible Films. Adv. Mater. 2006, 18, 2189-2194. [CrossRef]

33. Marton, D.; Boyd, K.J.; Al-Bayati, A.H.; Todorov, S.S.; Rabalais, J.W. Carbon nitride deposited using energetic species: A two-phase system. Phys. Rev. Lett. 1994, 73, 118-121. [CrossRef] [PubMed]

34. Ou, M.; Zhong, Q.; Zhang, S.; Nie, H.; Lv, Z.; Cai, W. Graphene-decorated 3D $\mathrm{BiVO}_{4}$ superstructure: Highly reactive (040) facets formation and enhanced visible-light-induced photocatalytic oxidation of NO in gas phase. Appl. Catal. B 2016, 193, 160-169. [CrossRef] 
35. Li, D.; Wang, W.; Jiang, D.; Zheng, Y.; Li, X. Surfactant-free hydrothermal fabrication of monoclinic $\mathrm{BiVO}_{4}$ photocatalyst with oxygen vacancies by copper doping. RSC Adv. 2015, 5, 14374-14381. [CrossRef]

36. Nair, P.K.; Huang, L.; Nair, M.T.S.; Hu, H.; Meyers, E.A.; Zingaro, R.A. Formation of p-type $\mathrm{Cu}_{3} \mathrm{BiS}_{3}$ absorber thin films by annealing chemically deposited $\mathrm{Bi}_{2} \mathrm{~S}_{3}$-CuS thin films. J. Mater. Res. 1997, 12, 651-656. [CrossRef]

37. Chen, Z.; Cao, M. Synthesis, characterization, and hydrophobic properties of $\mathrm{Bi}_{2} \mathrm{~S}_{3}$ hierarchical nanostructures. Mater. Res. Bull. 2011, 46, 555-562. [CrossRef]

38. Morgan, W.E.; Stec, W.J.; Wazer, J.R.V. Inner-orbital binding-energy shifts of antimony and bismuth compounds. Inorg. Chem. 1973, 12, 953-955. [CrossRef]

39. Lin, L.; Yang, Y.; Men, L.; Wang, X.; He, D.; Chai, Y.; Zhao, B.; Ghoshroy, S.; Tang, Q. A highly efficient $\mathrm{TiO}_{2} @ \mathrm{ZnO}$ n-p-n heterojunction nanorod photocatalyst. Nanoscale 2013, 5, 588-593. [CrossRef] [PubMed]

40. Petala, A.; Bontemps, R.; Spartatouille, A.; Frontistis, Z.; Antonopoulou, M.; Konstantinou, I.; Kondarides, D.I.; Mantzavinos, D. Solar light-induced degradation of ethyl paraben with $\mathrm{CuO}_{x} / \mathrm{BiVO}_{4}$ : Statistical evaluation of operating factors and transformation by-products. Catal. Today 2017, 280, 122-131. [CrossRef]

41. Dos Santos, W.S.; Almeida, L.D.; Afonso, A.S.; Rodriguez, M.; Mesquita, J.P.; Monteiro, D.S.; Lca, O.; Fabris, J.D.; Pereira, M.C. Photoelectrochemical water oxidation over fibrous and sponge-like $\mathrm{BiVO}_{4} / \beta-\mathrm{Bi}_{4} \mathrm{~V}_{2} \mathrm{O}_{11}$ photoanodes fabricated by spray pyrolysis. Appl. Catal. B 2016, 182, 247-256. [CrossRef]

42. Vogel, R.; Hoyer, P.; Weller, H. Quantum-Sized PbS, CdS, $\mathrm{Ag}_{2} \mathrm{~S}, \mathrm{Sb}_{2} \mathrm{~S}_{3}$, and $\mathrm{Bi}_{2} \mathrm{~S}_{3}$ Particles as Sensitizers for Various Nanoporous Wide-Bandgap Semiconductors. J. Phys. Chem. 1994, 98, 3183-3188. [CrossRef]

43. Wu, T.; Zhou, X.; Zhang, H.; Zhong, X. Bi ${ }_{2} \mathrm{~S}_{3}$ nanostructures: A new photocatalyst. Nano Res. 2010, 3 , 379-386. [CrossRef]

44. Bessekhouad, Y.; Mohammedi, M.; Trari, M. Hydrogen photoproduction from hydrogen sulfide on $\mathrm{Bi}_{2} \mathrm{~S}_{3}$ catalyst. Sol. Energy Mater. Sol. Cells 2002, 73, 339-350. [CrossRef]

45. Zhao, D.; Zong, W.; Fan, Z.; Fang, Y.W.; Xiong, S.; Du, M.; Wu, T.; Ji, F.; Xu, X. Synthesis of carbon-doped nanosheets $\mathrm{m}-\mathrm{BiVO}_{4}$ with three-dimensional (3D) hierarchical structure by one-step hydrothermal method and evaluation of their high visible-light photocatalytic property. J. Nanopart. Res. 2017, 19, 124. [CrossRef]

46. Tan, G.; Zhang, L.; Ren, H.; Wei, S.; Huang, J.; Xia, A. Effects of pH on the hierarchical structures and photocatalytic performance of $\mathrm{BiVO}_{4}$ powders prepared via the microwave hydrothermal method. ACS Appl. Mater. Interfaces 2013, 5, 5186-5193. [CrossRef] [PubMed]

47. Hood, M.A.; Landfester, K.; Muñozespí, R. The Role of Residue Acidity on the Stabilization of Vaterite by Amino Acids and Oligopeptides. Cryst. Growth Des. 2014, 14, 1077-1085. [CrossRef]

48. Rai, D.; Yui, M.; Schaef, H.; Kitamura, A. Thermodynamic Model For $\left.\mathrm{BiPO}_{4}(\mathrm{Cr}) \mathrm{And} \mathrm{Bi(OH}\right)_{3}(\mathrm{Am})$ Solubility In The Aqueous $\mathrm{Na}^{+}-\mathrm{H}^{+}-\mathrm{H}_{2} \mathrm{PO}_{4}{ }^{-}-\mathrm{HPO}_{4}{ }^{2-}-\mathrm{PO}^{3-}-\mathrm{OH}^{-}-\mathrm{Cl}^{-}-\mathrm{H}_{2} \mathrm{O}$ System. J. Solut. Chem. 2010, 39, 999-1019. [CrossRef]

49. Jiang, Y.R.; Lin, H.P.; Chung, W.H.; Dai, Y.M.; Lin, W.Y.; Chen, C.C. Controlled hydrothermal synthesis of $\mathrm{BiO}_{x} \mathrm{Cl}_{y} / \mathrm{BiO}_{m} \mathrm{I}_{n}$ composites exhibiting visible-light photocatalytic degradation of crystal violet. J. Hazard. Mater. 2015, 283, 787-805. [CrossRef] [PubMed]

50. Huang, S.T.; Jiang, Y.R.; Chou, S.Y.; Dai, Y.M.; Chen, C.C. Synthesis, characterization, photocatalytic activity of visible-light-responsive photocatalysts $\mathrm{BiO}_{x} \mathrm{Cl}_{y} / \mathrm{BiO}_{m} \mathrm{Br}_{n}$ by controlled hydrothermal method. J. Mol. Catal. A Chem. 2014, 391, 105-120. [CrossRef]

51. Ren, L.; Zhang, D.; Hao, X.; Xiao, X.; Gong, J.; Wang, M.; Tong, Z. Synthesis and photocatalytic performance of $\mathrm{Bi}_{2} \mathrm{~S}_{3} / \mathrm{SnS}_{2}$ heterojunction. Funct. Mater. Lett. 2016, 10, 1750004. [CrossRef]

52. Xue, C.; Yan, X.; Ding, S.; Yang, G. Monodisperse Ag-AgBr nanocrystals anchored on one-dimensional $\mathrm{TiO}_{2}$ nanotubes with efficient plasmon-assisted photocatalytic performance. RSC Adv. 2016, 6, 68653-68662. [CrossRef]

53. Tang, J.; Li, D.; Feng, Z.; Tan, Z.; Ou, B. A Novel $\mathrm{AgIO}_{4}$ Semiconductor with Ultrahigh Activity in Photodegradation of Organic Dyes: Insights into the Photosensitization Mechanism. Cheminform 2013, 4, 2151-2154.

54. Lin, H.P.; Lee, W.W.; Huang, S.T.; Chen, L.W.; Yeh, T.W.; Fu, J.Y.; Chen, C.C. Controlled hydrothermal synthesis of $\mathrm{PbBiO}_{2} \mathrm{Br} / \mathrm{BiOBr}$ heterojunction with enhanced visible-driven-light photocatalytic activities. J. Mol. Catal. A Chem. 2016, 417, 168-183. [CrossRef] 
55. Lin, H.P.; Chen, C.C.; Lee, W.W.; Lai, Y.Y.; Chen, J.Y.; Chen, Y.Q.; Fu, J.Y. Synthesis of a $\mathrm{SrFeO}_{3-x} / \mathrm{g}_{-} \mathrm{C}_{3} \mathrm{~N}_{4}$ heterojunction with improved visible-light photocatalytic activities in chloramphenicol and crystal violet degradation. RSC Adv. 2015, 6, 1-9. [CrossRef]

56. Yang, C.T.; Lee, W.W.; Lin, H.P.; Dai, Y.M.; Chi, H.T.; Chen, C.C. A novel heterojunction photocatalyst, $\mathrm{Bi}_{2} \mathrm{SiO}_{5} / \mathrm{g}-\mathrm{C}_{3} \mathrm{~N}_{4}$ : Synthesis, characterization, photocatalytic activity, and mechanism. RSC Adv. 2016, 6, 40664-40675. [CrossRef]

57. Du, M.; Xiong, S.; Wu, T.; Zhao, D.; Zhang, Q.; Fan, Z.; Zeng, Y.; Ji, F.; He, Q.; Xu, X. Preparation of a Microspherical Silver-Reduced Graphene Oxide-Bismuth Vanadate Composite and Evaluation of Its Photocatalytic Activity. Materials 2016, 9, 160. [CrossRef]

2017 by the authors. Licensee MDPI, Basel, Switzerland. This article is an open access article distributed under the terms and conditions of the Creative Commons Attribution (CC BY) license (http://creativecommons.org/licenses/by/4.0/). 